PLATE 2

1. Dorsal view of body in abdominal region. The relative positions of the proventriculus, gizzard and intestines are clearly outlined.

2. View of caecums injected with barium sulphate mash. The caecums were injected with barium sulphate mash via the rectum. Note the constriction at the junction of the caecums and rectum with the small intestine, and the constricted proximal portions and dilated distal portions of the caecums.

\title{
The Requirements of Poultry for Aneurin, Choline, Folic Acid, Nicotinic Acid, Pantothenic Acid and Riboflavin
}

\section{By J. Duckworth and G. M. Ellinger, Rowett Research Institute, Bucksburn, Aberdeenshire}

An assessment of the adequacy of vitamin supplies in rations for any class of stock requires information of two kinds: (I) the quantities of the different vitamins in feeds, and (2) the requirements of the animals of the class in question for these vitamins. Information on these two categories is given below.

The data for the vitamin content of common poultry feeding-stuffs have been collected from recent literature. These are given in Tables $I$ and 2 . Where individual values are not given, either data could not be found or the values reported were too inconsistent for an average value to be reliable.

Information about the vitamin needs of baby chicks is extensive. The requirements of growing and adult birds are less well known. The differences in requirements for producing hatching eggs, as compared with table eggs, have not been extensively studied. Few workers have extended their investigations beyond the question of hatchability to include studies of the effect of vitamin levels in the hen's diet upon viability and vigour of the chicks.

Standards of vitamin requirements of poultry were first put forward by a committee of the (U.S.A.) National Research Council (Committee on Animal Nutrition, 1944). A revision recently appeared (Bird, 1948 ). The recommended allowances are given in Table 3. The original values included a $20 \%$ margin of safety above estimated adequacy. This has been subtracted in compiling the present table. There were several omissions in the original table; some of these have been filled by values secured from the recent literature, a survey of which follows.

\section{Recent work on vitamin requirements of poultry}

Aneurin. There has been no recent report on the requirements of poultry for aneurin.

Choline. Only the chick seems to require a dietary source of choline; in older birds synthesis occurs. Hens given a semi-synthetic diet containing only $0.04 \%$ choline had an output of choline in eggs of four or five times the intake (Ringrose \& Davis, 1946). When a natural diet, extracted with boiling neutral ethanol to reduce the choline content to $0.03 \%$, was given, egg production and hatchability were only slightly less than in birds receiving the same diet supplemented with choline to raise the level to $0.21 \%$ (Lucas, Norris \& Heuser, 1946). 
Folic acid. Maximum growth at $4-6$ weeks of age was obtained with diets containing $0.045 \mathrm{mg}$. folic acid/roo g. Haemoglobin formation was normal in 4-week-old chicks

Table I. Aneurin, choline and folic acid content of common poultry feeding-stuffs (mg./100 g.)

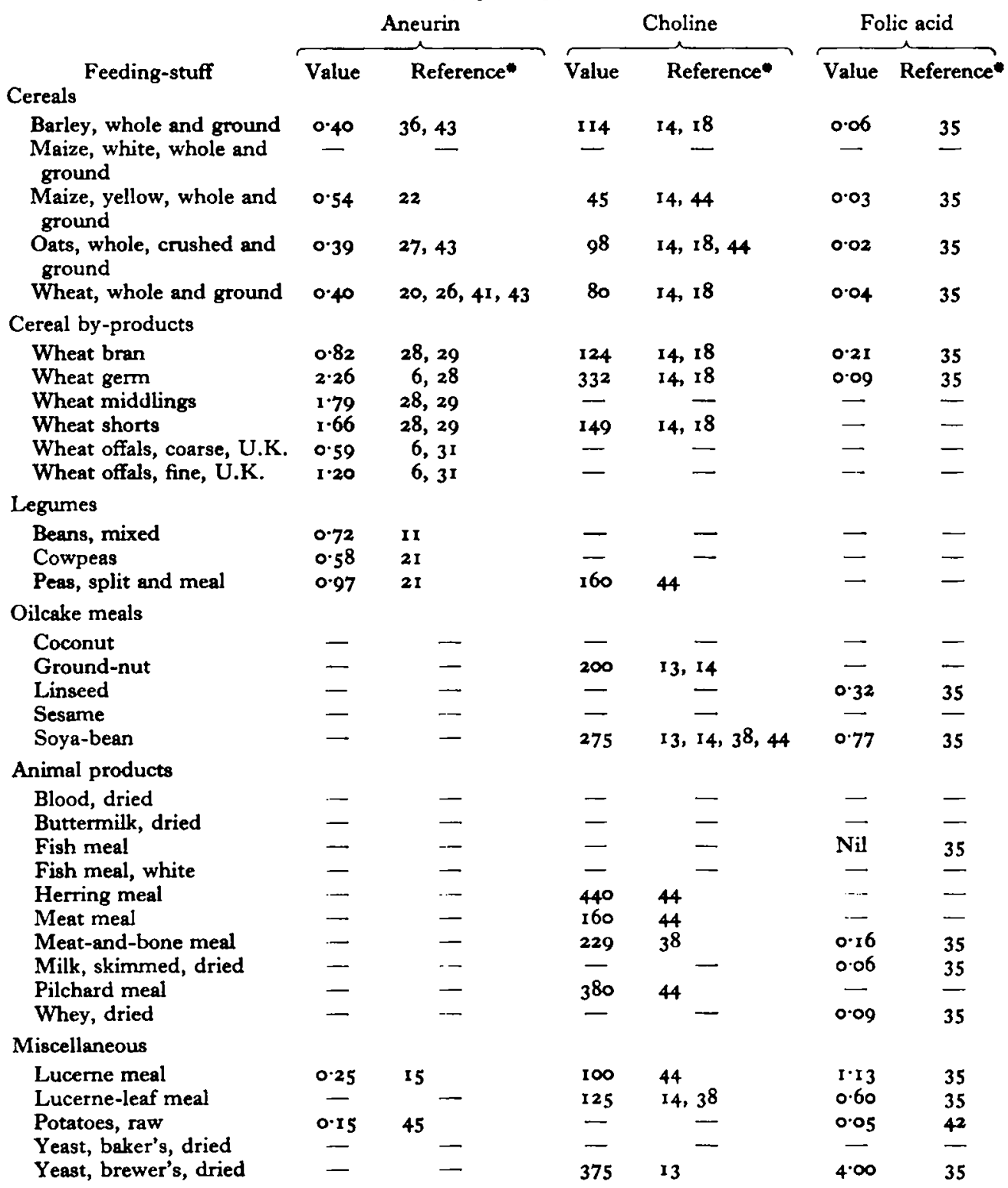

- The numbers refer to the References for composition of feeds on pp. 260-1.

on diets containing $0.045 \mathrm{mg}$, and 6-week-old chicks required only $0.035 \mathrm{mg} . / \mathrm{roog}$. For normal feathering at least $0.044 \mathrm{mg}$./ $100 \mathrm{~g}$. diet was needed (Robertson, Daniel, Farmer, Norris \& Heuser, 1946). Lillie \& Briggs (1947a) considered that 0.150 mg./ 
$100 \mathrm{~g}$. was necessary for normal growth and $0.200 \mathrm{mg} . / 100 \mathrm{~g}$. for normal feathering. Hutchings, Oleson \& Stokstad (1946) found that between 0.050 and $0.100 \mathrm{mg} . / 100 \mathrm{~g}$.

Table 2. Nicotinic acid, pantothenic acid and riboflavin content of common poultry feeding-stuffs

\begin{tabular}{|c|c|c|c|c|c|c|}
\hline \multirow[b]{3}{*}{ Feeding-stuff } & \multicolumn{4}{|c|}{$(\mathrm{mg} . / 100 \mathrm{~g})}$. & \multirow{2}{*}{\multicolumn{2}{|c|}{ Riboflavin }} \\
\hline & \multicolumn{2}{|c|}{ Nicotinic acid } & \multicolumn{2}{|c|}{ Pantothenic acid } & & \\
\hline & Value & Reference & Value & Reference & Value & Reference* \\
\hline \multicolumn{7}{|l|}{ Cereals } \\
\hline $\begin{array}{l}\text { Barley, whole and ground } \\
\text { Maize, white, whole and } \\
\text { ground }\end{array}$ & $\begin{array}{l}7 \cdot 0 \\
2 \cdot 6\end{array}$ & $\begin{array}{l}23,25,34,37 \\
34\end{array}$ & $\stackrel{0.86}{-}$ & 3,32 & $\begin{array}{l}0.13 \\
0.12\end{array}$ & $\begin{array}{l}I, 17,33,36 \\
I, 5\end{array}$ \\
\hline $\begin{array}{l}\text { Maize, yellow, whole and } \\
\text { ground }\end{array}$ & $2 \cdot 3$ & $23,30,34$ & 0.79 & $3,12,32$ & 0.11 & $1,5,17,33$ \\
\hline $\begin{array}{l}\text { Oats, whole, crushed and } \\
\text { ground }\end{array}$ & $1 \cdot 2$ & $23,34,37,46$ & 0.97 & 3 & 0.13 & $1,17,33,3^{6}$ \\
\hline Wheat, whole and ground & $6 \cdot 1$ & $23,25,34,37$ & 0.95 & $3,12,32$ & 0.12 & $1,17,36$ \\
\hline \multicolumn{7}{|l|}{ Cereal by-products } \\
\hline Wheat bran & $29 \cdot 0$ & 23,34 & $2 \cdot 48$ & 3,32 & 0.30 & $1,5,17,33$ \\
\hline Wheat germ & $4 \cdot 2$ & 34 & 0.70 & 32 & 0.55 & 17 \\
\hline Wheat middlings & $13 \cdot 0$ & 23,34 & $x \cdot 28$ & 3,32 & 0.40 & 8 \\
\hline Wheat shorts & - & - & $I \cdot 36$ & 3 & 0.28 & I, 33 \\
\hline Wheat offals, coarse, U.K. & $29 \cdot 4$ & $2,3 \mathrm{I}$ & 一 & 一 & 0.29 & 31 \\
\hline Wheat offals, fine, U.K. & $16 \cdot 3$ & $2,3^{1}$ & - & 一 & 0.34 & 31 \\
\hline \multicolumn{7}{|l|}{ Legumes } \\
\hline Beans, mixed & $2 \cdot 2$ & II & - & - & 0.18 & II, 33 \\
\hline Cowpeas & $2 \cdot 2$ & $7,19,34$ & $1 \cdot 80$ & 32 & 0.16 & 19 \\
\hline Peas, split and meal & $3 \cdot 3$ & 19,34 & $2 \cdot 10$ & 32 & 0.17 & 19,33 \\
\hline \multicolumn{7}{|l|}{ Oilcake meals } \\
\hline Coconut & - & - & $<0.10$ & 32 & 0.60 & 5 \\
\hline Ground-nut & - & - & $5 \cdot 30$ & 32 & 0.30 & 5,33 \\
\hline Linseed & $5 \cdot 1$ & $23,34,47$ & $<0.10$ & 32 & $0 \cdot 26$ & 17,33 \\
\hline Sesame & - & 一 & 0.60 & 32 & 0.44 & 5,33 \\
\hline Soya-bean & $3 \cdot 1$ & 23,34 & $1 \cdot 40$ & 3,32 & $0 \cdot 28$ & I 7,33 \\
\hline \multicolumn{7}{|l|}{ Animal products } \\
\hline Blood, dried & $2 \cdot 7$ & 47 & $<0.12$ & 32 & 0.05 & 17 \\
\hline Buttermilk, dried & $1 \cdot 7$ & 23 & $4 \cdot 20$ & 3,32 & 3.47 & $5,9,16,33$ \\
\hline Fish meal & - & - & 0.93 & 3 & 0.51 & $5,9,17,33$ \\
\hline Fish meal, white & - & 一 & - & - & 0.74 & $9,17,23$ \\
\hline Herring meal & - & - & - & - & 0.92 & 4 \\
\hline Meat meal & - & - & 0.10 & 3 & 0.46 & 17 \\
\hline Meat-and-bone meal & $6 \cdot 6$ & 23 & - & - & - & - \\
\hline Milk, skimmed, dried & $1 \cdot 8$ & 23,40 & $3 \cdot 25$ & 3,32 & $2 \cdot 30$ & $1,9,10,16,33$ \\
\hline Pilchard meal & - & - & - & 一 & - & - \\
\hline Whey, dried & $2 \cdot 6$ & 40 & $4 \cdot 63$ & 3,32 & $2 \cdot 00$ & $9,10,16,33$ \\
\hline \multicolumn{7}{|l|}{ Miscellaneous } \\
\hline $\begin{array}{l}\text { Lucerne meal } \\
\text { Lucerne-leaf meal }\end{array}$ & $\begin{array}{l}3 \cdot 4 \\
5 \cdot 3\end{array}$ & $\begin{array}{l}34,47 \\
23\end{array}$ & 3.04 & 3,32 & $\begin{array}{l}Y \cdot 21 \\
I \cdot 62\end{array}$ & $\begin{array}{r}24,33,34 \\
9,24,33\end{array}$ \\
\hline Potatoes, raw & - & - & 0.65 & 32 & 0.03 & 39 \\
\hline Yeast, baker's, dried & $45^{\circ} 0$ & 47 & - & - & - & - \\
\hline Yeast, brewer's, dried & $50 \cdot 0$ & 7,47 & $6 \cdot 28$ & 3 & 3.60 & 17 \\
\hline
\end{tabular}

- The numbers refer to the References for composition of feeds on pp. 260-I.

diet was needed to give growth and haemoglobin formation comparable with those of chicks receiving a commercial ration fortified with dried whole liver, dried brewer's 
yeast and cerophyl (dried powdered mixture of young leaves of wheat, oats and barley, manufactured by Cerophyl Laboratories, Kansas City, Missouri). Mills, Cottingham $\&$ Taylor (1947) found that the highest haemoglobin levels were obtained when the diet contained $0.050-0.100 \mathrm{mg}$. $/ 100 \mathrm{~g}$., although they found only a slight improvement in growth when levels above $0.010 \mathrm{mg}$./100 g. were given. Cravens \& Halpin (1949) considered that chick rations not favouring intestinal synthesis of folic acid, e.g., those rich in sugars, should contain between 0.050 and $0.100 \mathrm{mg} . / 100 \mathrm{~g}$.

Table 3. Aneurin, choline, folic acid, nicotinic acid, pantothenic acid and riboflavin requirements of poultry at different stages of growth and laying

\begin{tabular}{|c|c|c|c|c|}
\hline \multirow[b]{3}{*}{ Vitamin } & \multicolumn{2}{|c|}{ (mg./100 g. feed) } & & \\
\hline & \multicolumn{2}{|c|}{ Young bird } & \multicolumn{2}{|c|}{ Adult bird } \\
\hline & $0-8$ weeks & $8-18$ weeks & Laying & Breeding \\
\hline Aneurin & 0.17 & - & - & - \\
\hline Choline & 128 & -. & $(30-40)$ & $(30-40)$ \\
\hline Folic acid & $(0.05-0.10)^{*}$ & - & $(0.012) *$ & $(0.025)^{*}$ \\
\hline Nicotinic acid & $\times \cdot 47$ & 一 & - & -- \\
\hline Pantothenic acid & 0.92 & - & 0.46 & 0.92 \\
\hline Riboflavin & 0.29 & 0.17 & 0.17 & 0.24 \\
\hline
\end{tabular}

- Values in parentheses added from the literature; remainder of values from Bird (1948).

Egg production was normal on rations containing $0.012 \mathrm{mg} . / \mathrm{ro0}$ g., although the requirement for normal hatchability appeared to be somewhat higher (Taylor, 1947). Cravens \& Halpin (1949) suggested that not more than $0.025 \mathrm{mg} . / \mathrm{r} 00 \mathrm{~g}$. is necessary for normal hatching, and Schweigert, German, Pearson \& Sherwood (1948) found that less than $0.042 \mathrm{mg}$./100 g. was enough.

An antagonism between folic acid and $p$-aminobenzoic acid was observed by Lillie $\&$ Briggs ( $1947 b$ ), who found that the advantages gained when folic acid was added to a synthetic ration were partly lost when $p$-aminobenzoic acid was also added.

Nicotinic acid. There has been no recent work on the requirements of poultry for nicotinic acid under feeding conditions approaching normal. Various workers have studied the increase in the nicotinic acid requirement of chicks receiving rations rich in maize or gelatine. In extreme cases the nicotinic acid requirement of the chick may be raised to at least $5 \mathrm{mg}$./ $100 \mathrm{~g}$. diet, and bone ossein produces nicotinic acid deficiency in laying hens, with loss of weight, reduced egg production and low hatchability (Briggs, Groschke \& Lillie, 1946).

Nicotinic acid deficiency was observed with a 'commercial ration' containing $55 \%$ maize and $34.5 \%$ soya-bean meal (Berry, Carrick, Roberts \& Hauge, 1943).

Pantothenic acid. The requirement of hens for normal egg production was not over $0.15 \mathrm{mg}$./ $100 \mathrm{~g}$. diet, but at least $0.800 \mathrm{mg}$. $/ 100 \mathrm{~g}$. was required to sustain normal hatchability and to secure chicks of high viability with good growth rates (Gillis, Heuser \& Norris, 1948).

Riboflavin. Bolton (1947) found that the amount of riboflavin required for good growth in chicks was $0.30-0.35 \mathrm{mg} . / 100 \mathrm{~g}$. diet, and that $0.36 \mathrm{mg} . / 100 \mathrm{~g}$. prevented 
curled-toe paralysis. These values are slightly above those given in Table 3, perhaps because chicks depleted of riboflavin were used in the test.

Battery-kept yearling pullets showed rises in tissue levels of riboflavin as increasing amounts of the vitamin were given (Stamberg, Petersen \& Lampman, 1947). There was little increase in tissue riboflavin at dietary levels above $0.5 \mathrm{I} \mathrm{mg} . / 100 \mathrm{~g}$. Artificially inseminated birds in batteries required $0.36 \mathrm{mg} . / 100 \mathrm{~g}$. diet for normal hatchability of eggs. Raising the intake to $0.5 \mathrm{I} \mathrm{mg} . / \mathrm{r} 00 \mathrm{~g}$. feed did not improve hatchability, but the quality of the chicks was better (Petersen, Lampman \& Stamberg, 1947 b). The highest percentage transfer of dietary riboflavin to eggs $(39 \%)$ took place at an intake level of $0.36 \mathrm{mg} . / 100 \mathrm{~g}$. diet, and above $0.5 \mathrm{I} \mathrm{mg} . / 100 \mathrm{~g}$. the total transfer was but little greater (Petersen et al. 1947a).

\section{Special factors conditioning vitamin provision for poultry}

Storage losses in feeding-stuffs. Under normal conditions of storage, losses of watersoluble vitamins seem unlikely. Ground and unground samples of cereals, legumes, hays and lucerne-leaf meals were stored individually in the dark at $25^{\circ}$ for I year without loss of aneurin, biotin, nicotinic acid or pantothenic acid (Lardinois, Elvehjem $\&$ Hart, 1944). There was no loss of choline from poultry mashes stored for 6 months (Cooley \& Christiansen, 1948). Exposure of mashes to direct sunlight for 2 weeks caused only small losses of riboflavin (Stamberg \& Petersen, 1946).

Environmental factors affecting requirement. Under experimental conditions simulating the insular tropics-temperatures of $90-91^{\circ} \mathrm{F}$. and relative humidities of 60$70 \%$-the aneurin requirement of chicks up to 5 weeks of age was raised from 0.10 to $0.30 \mathrm{mg} . / 100 \mathrm{~g}$. diet. The requirements for folic acid, nicotinic acid, pyridoxin and choline were not altered (Mills et al. 1947).

Genetic factors affecting requirement. White Leghorn chicks required less aneurin than Rhode Island Red chicks, whose needs were met by feeds containing $0.120 \mathrm{mg} / \mathrm{r} 00 \mathrm{~g}$. (Lamoreux \& Hutt, 1939).

Breed differences also exist in the amount of aneurin transmitted in the egg. Under comparable conditions White Leghorns laid eggs containing $0.105 \mathrm{mg} . / 100 \mathrm{~g}$. contents, whereas those laid by Rhode Island Reds and Barred Plymouth Rocks contained 0.064 and $0.066 \mathrm{mg}$. $/$ oo g. respectively (Scrimshaw, Hutt \& Scrimshaw, 1945).

By means of selection over six generations Lamoreux \& Hutt (1948) produced a strain of White Leghorns less susceptible to riboflavin deficiency. The resistant strain was poor by commercial standards.

Lillie \& Briggs (1947a) obtained a poorer response from White Leghorn than from. New Hampshire chicks in growth tests to determine the adequacy of a given level of folic acid.

Droppings as a source of vitamins. The riboflavin content of droppings increased by about $100 \%$ during $24 \mathrm{hr}$. at room temperature. The increase was about $300 \%$ in I week (Lamoreux \& Schumacher, 1940). The organism responsible was isolated (Schumacher \& Heuser, 194r). It seems possible that droppings may contribute small amounts of riboflavin to the hen's diet, so that moderate deficiencies in the ration may 
be rectified. These findings probably explain the higher levels of riboflavin requirement as compared with the values in Table 3, found by Petersen and co-workers (cited above).

\section{Vitamin adequacy of present-day poultry rations}

Fifteen poultry rations-five each of starting, growing and laying mashes-were constructed to comply with the regulations of the Ministry of Food governing the composition and ingredients of poultry feeds [The Feeding Stuffs (Regulation of

Table 4. Vitamin content of five National Baby Chick Food rations complying with Ministry of Food regulations

\begin{tabular}{|c|c|c|c|c|c|c|}
\hline Ration no. & Aneurin & Choline & $\begin{array}{l}\text { Folic } \\
\text { acid }\end{array}$ & $\begin{array}{l}\text { Nicotinic } \\
\text { acid }\end{array}$ & $\begin{array}{l}\text { Pantothenic } \\
\text { acid }\end{array}$ & Riboflavin \\
\hline I & 0.56 & 116 & 0.079 & $6 \cdot 76$ & $1 \cdot 09$ & 0.36 \\
\hline 2 & 0.60 & 120 & 0.086 & $6 \cdot 78$ & $I \cdot I I$ & 0.38 \\
\hline $3 *$ & 0.59 & 127 & 0.180 & 7.65 & $I \cdot 14$ & 0.38 \\
\hline $4 *$ & 0.55 & I 15 & 0.132 & 6.40 & $1 \cdot 17$ & 0.40 \\
\hline $5^{*}$ & 0.57 & 124 & 0.159 & $7 \cdot 79$ & $I \cdot 18$ & 0.41 \\
\hline Requirementt & 0.17 & 128 & $(0.05-0.10)$ & $1 \cdot 47$ & 0.92 & 0.29 \\
\hline
\end{tabular}

- Containing dried brewer's yeast.

† See Table 3 .

Table 5. Vitamin content of five National Poultry Food No. 2 (Growing Mash) rations complying with Ministry of Food regulations

\begin{tabular}{ccccccc}
\multicolumn{7}{c}{ (mg./100 g. feed) } \\
Ration no. & Aneurin & Choline & $\begin{array}{c}\text { Folic } \\
\text { acid }\end{array}$ & $\begin{array}{c}\text { Nicotinic } \\
\text { acid }\end{array}$ & $\begin{array}{c}\text { Pantothenic } \\
\text { acid }\end{array}$ & Riboflavin \\
I & 0.66 & 128 & 0.102 & 8.87 & 0.98 & 0.24 \\
2 & 0.62 & 114 & 0.088 & 7.01 & 0.92 & 0.23 \\
3 & 0.66 & 115 & 0.112 & 8.30 & 0.93 & 0.25 \\
4 & 0.68 & 113 & 0.095 & 7.86 & 1.19 & 0.23 \\
$5^{*}$ & 0.63 & 120 & 0.237 & 7.90 & $1 \cdot 21$ & 0.37 \\
Requirement & - & - & - & - & - & 0.17
\end{tabular}

Manufacture) Order, 1948 (Amendment Order 1948)]. The five rations constructed for each type of mash were such that at least one of the rations could have been made up during the last 2 years, according to the Cereal Coupon Split in force. The vitamin contents of the rations are given in Tables 4,5 and 6, together with appropriate standards of requirements taken from Table 3 .

The comparisons given below relate to birds fed exclusively on the appropriate mashes. Where stock has access to grass runs and can prey upon the lesser fauna the conclusions drawn may not be valid.

Starting mashes (Table 4). The margin of safety is greatest for aneurin and nicotinic acid; the supplies are three to five times the requirement. The supply of folic acid in the mashes is well above the lower limit $-0.05 \mathrm{mg} . / 100 \mathrm{~g}$. diet. Rations containing dried brewer's yeast are above the upper limit. Both riboflavin and pantothenic acid 
are present in amounts sufficient to provide margins of safety of about $20-40 \%$. Choline alone is at the borderline level of requirement.

Growing mashes (Table 5). It is difficult to evaluate the adequacy of the vitamin provision of the rations in the absence of reliable standards of requirements for growing birds. The rations provide amounts of the different vitamins closely similar to those of the starting mashes, except for riboflavin of which the provision is about one-third less.

Table 6. Vitamin content of five National Poultry Food No. I (Laying Mash) rations complying with Ministry of Food regulations

\begin{tabular}{ccccccc}
\multicolumn{7}{c}{ (mg./roo g. feed) } \\
Ration no. & Aneurin & Choline & $\begin{array}{c}\text { Folic } \\
\text { acid }\end{array}$ & $\begin{array}{c}\text { Nicotinic } \\
\text { acid }\end{array}$ & $\begin{array}{c}\text { Pantothenic } \\
\text { acid }\end{array}$ & Riboflavin \\
1 & 0.60 & 106 & 0.087 & 6.97 & 0.95 & 0.22 \\
2 & 0.66 & 110 & 0.106 & 7.46 & 0.73 & 0.25 \\
3 & 0.66 & 122 & 0.094 & 7.78 & 1.08 & 0.25 \\
$4^{*}$ & 0.60 & 132 & 0.299 & 9.04 & 1.28 & 0.42 \\
$5^{*}$ & 0.69 & 134 & 0.249 & 8.97 & 1.31 & 0.39 \\
$\begin{array}{l}\text { Requirementt } \\
\text { Laying }\end{array}$ & - & $(30-40)$ & $(0.012)$ & - & 0.46 & 0.17 \\
Breeding & - & $(30-40)$ & $(0.025)$ & - & 0.92 & 0.24
\end{tabular}

- Containing dried grass and dried brewer's yeast.

† See Table 3.

Since adult birds laying eggs for eating purposes require less of the vitamins under consideration per $100 \mathrm{~g}$. feed than chicks, it seems unlikely that the vitamin provision is inadequate. For riboflavin, where the requirement is known, a margin of safety of about $50 \%$ is provided.

Laying mashes (Table 6). Although no information is available about the requirements for aneurin and nicotinic acid, it is unlikely that risks of deficiency exist. The amount of nicotinic acid present is well above the lower limit of $5 \mathrm{mg} . / \mathrm{r} \infty \mathrm{g}$. feed recommended for experimental chick rations prone to produce deficiency through their high content of maize and gelatine. Choline and folic acid are present in amounts well above requirements. Pantothenic acid is present with an ample margin of safety for birds laying eggs for eating; for breeding stock one ration is borderline and one is deficient. All rations are adequate in riboflavin for birds laying eating eggs. For breeding stock the provision of riboflavin is marginal, except in cases where dried grass and dried brewer's yeast are included in the ration.

\section{SUMMARY}

I. A compilation of data on the amounts of certain vitamins in some common poultry feeding-stuffs is given.

2. Information on vitamin requirements to supplement the (U.S.A.) National Research Council's standards is presented.

3. The adequacy of the vitamin content of typical poultry rations complying with Ministry of Food regulations has been assessed. 


\section{REFERENCES}

Berry, E. P., Carrick, C. W., Roberts, R. E. \& Hauge, S. M. (r943). Poult. Sci. 22, 252.

Bird, H. R. (1948). Circ. U.S. Dep. Agric. no. 788.

Bolton, W. (1947). F. agric. Sci. 37, 316.

Briggs, G. M., Groschke, A. C. \& Lillie, R. J. (1946). F. Nutrit. 32, 659.

Committee on Animal Nutrition (1944). Recommended Nutrient Allowances for Poultry. Washington, D.C.: National Research Council.

Cooley, M. L. \& Christiansen, J. B. (1948). Poult. Sci. 27, 822.

Cravens, W. W. \& Halpin, J. G. (1949). F. Nutrit. 37, 127.

Gillis, M. B., Heuser, G. F. \& Norris, L. C. (I948). F. Nutrit. 35, 35 I.

Hutchings, B. L., Oleson, J. J. \& Stokstad, E. L. R. (1946). F. biol. Chem. 163, 447.

Lamoreux, W. F. \& Hutt, F. B. (1939). F. agric. Res. 58, 307.

Lamoreux, W. F. \& Hutt, F. B. (1948). Poult. Sci. 27, 334.

Lamoreux, W. F. \& Schumacher, A. E. (1940). Poult. Sci. 19, 418.

Lardinois, C. C., Elvehjem, C. A. \& Hart, E. B. (1944). F. Dairy Sci. 27, 875.

Lillie, R. J. \& Briggs, G. M. (1947a). Poult. Sci. 26, 295.

Lillie, R. J. \& Briggs, G. M. (1947b). Poult. Sci. 26, 549.

Lucas, H. L., Norris, L. C. \& Heuser, G. F. (1946). Poult. Sci. 25, 373.

Mills, C. A., Cottingham, E. \& Taylor, E. (1947). Amer. Y. Physiol. 149, 376.

Petersen, C. F., Lampman, C. E. \& Stamberg, O. E. (1947a). Poult. Sci. 26, r80.

Petersen, C. F., Lampman, C. E. \& Stamberg, O. E. (1947b). Poult. Sci. 26, 187.

Ringrose, R. C. \& Davis, H. A. (1946). Poult. Sci. 25, 646.

Robertson, E. I., Daniel, L. J., Farmer, F. A., Norris, L. C. \& Heuser, G. F. (1946). Poult. Sci. $25,411$.

Schumacher, A. E. \& Heuser, G. F. (1941). Poult. Sci. 20, 272.

Schweigert, B. S., German, H. L., Pearson, P. B. \& Sherwood, R. M. (1948). Ұ. Nutrit. 35, 89.

Scrimshaw, N. S., Hutt, F. B. \& Scrimshaw, M. W. (1945). F. Nutrit. 30, 375.

Stamberg, O. E. \& Petersen, C. F. (1946). Poult. Sci. 25, 394.

Stamberg, O. E., Petersen, C. F. \& Lampman, C. E. (1947). Poult. Sci. 26, I 26.

Taylor, L. W. (1947). Poult. Sci. 26, 372.

\section{REFERENCES TO TABLES I AND 2}

I. Andrews, J. S., Boyd, H. M. \& Terry, D. E. (1942). Cereal Chem. I9, 55.

2. Barton-Wright, E. C. (1944). Biochem. F. 38, 314.

3. Bauernfeind, J. C., Norris, L. C. \& Heuser, G. F. (1942). Poult. Sci. 21, 136.

4. Billings, F. L., Biely, J., Fisher, H. \& Hedreen, C. (1941). F. Nutrit. 22, 425.

5. Bondi, A. \& Meyer, H. (1946). F. agric. Sci. 36, 6.

6. Booth, R. G., Carter, R. H., Jones, C. R. \& Moran, T. (194I). Chem. \& Ind. 60, 903

7. Brown, E. B., Thomas, J. M. \& Bina, A. F. (1946). F. biol. Chem. 162, 221.

8. Copping, A. M. (1943). Biochem. F. 37, 12.

9. Culton, T. G. \& Bird, H. R. (r94I). Poult. Sci. 20, 3.

ro. Daniel, L. \& Norris, L. C. (1944). Food Res. 9, 312.

I I. Daniel, L. \& Norris, L. C. (1945). F. Nutrit. 30, 3 1.

12. Elvehjem, C. A. (1942). Э. Amer. diet. Ass. 18, 145.

13. Engel, R. W. (1942). F. biol. Chem. 144, 701.

14. Engel, R. W. (1943). F. Nutrit. 25, 441.

15. Escudero, P. \& Landabure, P. B. (1943). Rev. Asoc. argent. dietol. 1, 143.

16. Evans, E. V., Young, D. M. \& Branion, H. D. (1944). Sci. Agric. 24, 5 10.

17. Evans, E. V., Young, D. M. \& Branion, H. D. (1945). Sci. Agric. 25, 542.

18. Glick, D. (1945). Cereal Chem. 22, 95.

19. Golberg, L., Kropman, M. \& Thorp, J. M. (1947). S. Afr. F. med. Sci. 12, I71.

20. Golberg, L. \& Thorp, J. M. (1942). S. Afr. F. med. Sci. 7, 95.

21. Golberg, L., Thorp, J. M. \& Sussman, S. (1945). S. Afr. F. med. Sci. 10, 87.

22. Guillemet, R. \& Petit, L. (1947). Ann. Nutrit. Aliment. I, 83.

23. Hale, E. B., Davis, G. K. \& Baldwin, H. R. (1942). J. biol. Chem. 146, 565 .

24. Hanke, A. R. \& Perkins, A. T. (1942). Poult. Sci. 21, 195.

25. Hausman, E., Rosner, L. \& Cannon, H. J. (1943). Cereal Chem. 20, 82.

26. Hoffer, A., Alcock, A. W. \& Geddes, W. F. (1944). Cereal Chem. 21, 210.

27. Holman, W. I. M. \& Godden, W. (1947). F. agric. Sci. 37, 5 I.

28. Jackson, S. H., Doherty, A. \& Malone, V. (1943). Cereal Chem. 20, 551.

29. Jackson, S. H. \& Whiteside, A. G. O. (1942). Sci. Agric. 22, 366. 
30. James, E. M., Norris, F. W. \& Wokes, F. (1947). Analyst, 72, 327.

31. Jones, C. R. \& Moran, T. (1946). Cereal Chem. 23, 248.

32. Jukes, T. H. (1941). F. Nutrit. 21, 193.

33. Kemmerer, A. R. \& Fraps, G. S. (1945). Bull. Tex. agric. Exp. Sta. no. 671.

34. Krehl, W. A., Huerga, J. de la, Elvehjem, C. A. \& Hart, E. B. (1946). F. biol. Chem. 166, 53.

35. Lillie, R. J. \& Briggs, G. M. (1947). Poult. Sci. 26, 289.

36. McElroy, L. W., Kastelic, J. \& McCalla, A. G. (1948). Canad. F. Res. 26, sect. F, p. 191.

37. McElroy, L. W. \& Simonson, H. (1948). Canad. F. Res. 26, sect. F, p. 201 .

38. Marvel, J. A., Carrick, C. W., Roberts, R. E. \& Hauge, S. M. (1945). Poult. Sci. 24, I8I.

39. Munsell, H. E. (1942). Food Res. 7, 85.

40. Noll, C. I. \& Jensen, O. G. (194I). F. biol. Chem. 140, 755.

41. O'Donnell, W. W. \& Bayfield, E. G. (1947). Food Res. 12, 212.

42. Olson, O. E., Burris, R. H. \& Elvehjem, C. A. (1947). Э. Amer. diet. Ass. 23, 200.

43. Pulkki, L. H. \& Puutula, K. (1947). Cereal Chem. 24, 337.

44. Rhian, M., Evans, R. J. \& St John, J. L. (1943). F. Nutrit. 25, I.

45. Scheunert, A. \& Wagner, K. H. (1938). Biochem. Z. 295, I83.

46. Täufel, K. \& Dontscheff, J. (1944). Z. Lebensmitt. 87, 187.

47. Teply, L. J., Strong, F. M. \& Elvehjem, C. A. (1942). F. Nutrit. 23, 417.

\title{
The Fat-Soluble Vitamins in Poultry Nutrition
}

\author{
By M. E. Contes, Cod-Liver Oil (Poultry) Standardization Laboratory, \\ National Institute for Research in Dairying, University of Reading
}

\section{Historical introduction}

The importance of most of the fat-soluble vitamins in poultry nutrition has been recognized for a long time. A considerable amount of work has been done to establish the requirements of poultry for these vitamins under different conditions.

\section{Vitamins $A$ and $D$}

Sugiura \& Benedict (1923) carried out experiments with pigeons from which they concluded that 'fat-soluble vitamine is not essential in any stage of avian nutrition'. This unjustified statement was immediately challenged by Emmett \& Peacock (1923), who showed that unless vitamin A was included in the diet of growing chicks they died, with lesions of the eye and renal deposits of urates, young chicks being more susceptible to the deficiency than older ones. This work was confirmed in a series of experiments by Hart, Steenbock, Lepkovsky \& Halpin (1923, 1924).

In the same experiments the need of chicks for vitamin $D$ also became apparent. Hart, Halpin \& Steenbock (1920) produced 'leg weakness' in chicks by feeding a synthetic diet, and were unable to cure it with green vegetables. Two years later the same authors (Hart et al. 1922) concluded that factors present in cod-liver oil were needed to prevent rickets in the growing chick. The following year Hart, Steenbock, Lepkovsky \& Halpin (1923) realized the importance of sunlight for birds deprived of the antirachitic vitamin, but it was not until some years later that the inefficient utilization of some forms of vitamin D by poultry was recognized (Mussehl \& Ackerson, 1930).

\section{Vitamin $E$}

The first work on the role of vitamin $E$ in poultry nutrition came from Card (1928), who studied it in hens in connexion with fertility and hatchability. As vitamin $E$ is so 